\title{
A COMPLEX APPROACH TO THE DEFINITION OF CONCEPT "SOCIAL PORTRAIT OF INTERNET USER"
}

\begin{abstract}
у статmі здійснюється спроба комплексного підходу до визначення соціального портрету інтернет-користувача. Тема $\epsilon$ актуальною, оскільки в результаті діджиталізації усіх сорер суспільства, перебування в інтернеті, реєстрація в соціальних мережах, фрорумах чи сайтах стають звичними практиками в сучасних реаліях. Такі практики зумовлюються різними причинами, проте в будь-якому разі людина залишає по собі так званий «інформаційний слід», що дозволяє зробити певні висновки про ії особистість. Зважаючи на швидкість, маситабність та доступність інформації про користувачів в інтернеті, аналіз віртуальних даних стає надзвичайно популярною темою в науиі та продуктивною сферою в бізнесі. За допомогою обробки інфрормаціі в інтернеті формується портрет користувача, який у різних галузях використовується для специорічних потреб. Ці потреби можуть бути спрямовані як на розвиток суспільства, так і на його дестабілізацію. Комплексний підхід до визначення поняття «соціальний портрет інтернет-користувача» дозволить, по-перше, розмежувати наявні міждисциплінарні підходи до трактування терміну, по-друге, з'ясувати різносторонні причини використання інсрормації про користувачів мережі, по-третє, виявити соціальні наслідки такого процесу. В результаті синтезу міждисциплінарних підходів визначаються основні компоненти сочіального портрету інтернет-користувача - соціально-демографічний блок, ідентифрікаційний блок та поведінковий блок. Аналізуючи праці науковців з різних сорер, було виявлено, що інфрормацію для цих компонентів можна роздобувати кількома способами (або з їх поєднанням) - від застосування спеціального програмного забезпечення до сочіологічних досліджень. Було виявлено проблему використання технології формування портрету інтернет-користувача у неправомірних та несхвалених суспільством діях, передусім пов'язаних з маніпуляцією свідомістю користувача. Тому у статті подаються рекомендації для використання соціального портрету інтернет-користувача задля ефективного фрункціонування суспільства та його членів.
\end{abstract}

ключові слова: комплексний підхід, соціальний портрет інтернет-користувача, ідентифрікація користувача, інтернетповедінка, віртуальна ідентичність.

The article attempts a complex approach to determine the social portrait of the Internet user. The topic is relevant because as a result of digitalization of all social spheres, online-session, registration in social networks, forums or sites become common practices in modern realities. Such practices are due to various reasons. However, in any case, a person leaves an "information trail" behind, which allows to draw certain conclusions about their personality. Due to the speed, scale and availability of information about users on the Internet, the analysis of virtual data is becoming an extremely popula topic in science and productive field in business. By processing information on the Internet, a portrait of the user can be made and used in various fields for specific needs. These needs can be aimed at both the development of society and its destabilization. A complex approach to defining the concept of "social portrait of the Internet user" will, firstly, distinguish between existing interdisciplinary approaches to the interpretation of the term, secondly, to clarify the various reasons for using information about network users and, thirdly, to identify social consequences such a process. As a result of the synthesis of interdisciplinary approaches, main components of a social portrait of the Internet user are determined - the socio-demographic block, the identification block and the behavioral block. Analyzing the work of scientists from different fields, it was found that information for these components can be obtained in several ways (or a combination of them) - from the use of special software to sociological research. The problem of using the technology of forming a portrait of an Internet user in illegal and disapproved by society actions, primarily related to manipulation of the user's consciousness, was revealed. Therefore, the article provides recommendations for the use of the Internet user's social portrait for effective functioning of society and its members.

Key words: complex approach, social portrait of the Internet user, user identification, Internet behavior, virtual identity.
Постановка проблеми. Сьогодні вже нікого не можна здивувати своєю присутністю в інтернеті. Навпаки, коли хтось стверджує, що не має відношення до мережі, це викликає свого роду шок з подальшою ідентифікацією тієї особи як «динозавра». Відсутність в інтернеті зараз може прирівнюватись до того, що людини не існувало взагалі. Натомість відсутність особи в інтернеті не завжди означає, що даних про неї немає в мережі. Така ситуація відбувається у зв'язку з діджиталізацією суспільства. За все своє життя людина потрапляе у велику кількість реєстрів, які зараз фіксуються у цифрових базах даних. Крім цього, людина добровільно ділиться особистою інформацією, реєструючись у соціальних мережах, форумах, сайтах, пошті тощо. Відтак інтернет стає невичерпним джерелом найновішої інформації про користувачів, з допомогою якого мож- 
ливо формувати образ людини у віртуальному середовищі. Конструювання портрету інтернет-користувача $€$ досить поширеною практикою у визначених сферах, що використовується для різних потреб та приносить ефективні результати. Таким чином, окреслена тема стає об'єктом аналізу численних наук, серед яких ряд економічних наук (особливо маркетинг), психологія, політологія, комп'ютерні науки та соціологія.

Постановка завдання. Зважаючи на актуальність тематики, мета статті - на основі аналізу міждисциплінарної наукової літератури сформувати комплексний підхід до визначення соціального портрету інтернет-користувача.

Виклад основного матеріалу. Для початку варто зазначити, що використання термінологічного конструкту «соціальний портрет інтернет-користувача» практично не здійснюється в іноземній та вітчизняній науковій літературі. Проте зустрічаються категорії, що володіють певними характеристиками, які лише частково розкривають його значення. Тому терміни «ідентифікація користувача», «соціально-демографічний портрет користувача» чи «психологічний портрет користувача» не варто вважати синонімічними до соціального портрету інтернет-користувача.

Синтез підходів з різних галузей наукового знання дозволить отримати цілісну картину того, яким чином здійснюється формування саме соціального портрету інтернет-користувача. Водночас це дозволить розмежувати підходи до аналізу заданої тематики. Необхідно підкреслити, що в рамках цієї статті не здійснюється поглиблений аналіз обраної проблеми в певній галузі, а досліджується той аспект, який дозволить здійснити комплексний підхід та соціологічну інтерпретацію категорії «соціальний портрет інтернет-користувача».

Специфіка підходу науковців в сфері комп'ютернихнаукполягає у розгляді, вивченні та створенні технічних засобів, математичних моделей задля отримання різного роду інформації про інтернет-користувача. Цей процес позначається терміном «ідентифікація користувача в мережі інтернет». За допомогою такої технології з'являється можливість формувати портрет користувача, тобто дізнатися веб-контент, який створив користувач, його персональні дані. Способи використання ідентифікації користувачів різноманітні: виявлення ботів, шахрайства в інтернеті, розпізнавання цілеспрямованих атак, викриття вторгнення у конфіденційність користувача, деталізація персональних даних для можливості формування контекстної реклами, таргетингу інформації (виокремлення цільової аудиторії, концентрування інформації саме на цільовій аудиторії, подання контекстозалежної інформації - за інтересами, за соціально-демографічними характеристиками, за часом, за психологічними якостями).

Науковці в галузі комп'ютерної та математичної лінгвістики Т. Говорущенко, Д. Медзатий та В. Семенюк стверджують, що способів ідентифікації користувача в інтернеті $є$ безліч, причому бувають такі, які просто неможливо нейтралізувати, оскільки вони працюють непомітно для користувача [2, с. 79].

Дослідники визначають такі найпопулярніші способи ідентифікації користувачів в інтернеті: cookies, за допомогою явних ідентифікаторів, характеристик комп'ютера (адреса, тип використовуваної операційної системи, час, які можна отримати з НТТР-заголовків відправлених запитів), поведінкового аналізу та звичок користувача (рух курсора, улюблені розділи та сайти) [2, с. 75].

А. Гомзін та С. Кузнецов, науковці в галузі системного програмування, в своїй роботі покроково описали специфіку та методи побудови соціально-демографічних профілів користувачів інтернет. Найпопулярнішим джерелом даних для реалізації такої мети дослідники називають різноманітні соціальні мережі, зокрема Facebook, Twitter, Youtube. Facebook серед них $є$ найбільш інформативним джерелом, оскільки в цій найбільш чисельній в світі соціальній мережі користувачі часто вносять певні атрибути соціально-демографічного характеру (стать, вік, освіта, географічні дані, сімейний стан, працевлаштування тощо). Отримати необхідні дані можливо за допомогою певних математичних моделей та програм, зокрема А. Гомзін та С. Кузнецов згадують про машинне навчання з учителем, що може класифікувати користувачів навіть тоді, коли в профілі не внесені якісь конкретні атрибути, використовуючи обробку інших характеристик: аналіз текстів, смайликів, «хештегів» тощо [3, с. 131].

Здобуті за допомогою таких методів атрибути користувачів класифікуються та узагальнюються, що дає змогу використовувати отримані дані для розробки ефективної таргетованої реклами та collaborative recommender system (прогностичних програм), тобто $€$ стратегічно важливим елементом економічної сфери.

3 погляду маркетингового підходу користувачів інтернету інтерпретують як споживачів можливостей віртуального середовища.

Для інтернет-маркетингу достатньо важливим $€$ знати онлайн-аудиторію як в генералізуючій величині, так і в конкретних значеннях, наприклад, для аналізу аудиторії визначеного сайту, аби прослідкувати тенденції споживання товару чи послуги в певному регіоні. Такого роду дослідження важливі задля визна- 
чення та коригування контенту цього сайту для ефективного збуту.

Науковець у сфері інтернет-маркетингу І. Литовченко, називаючи структуру інтернет-аудиторії рухомою та залежною від різних чинників, визначає три рівні коливань аудиторії, тобто активності інтернет-користувачів: річний, місячний та тижневий [4].

Так, на річному рівні найбільші впливи на активність інтернет-аудиторії здійснює соціально-політичний чинник, пов'язаний зі зміною настроїв у суспільстві, викликаними, наприклад, черговими виборами.

Місячні коливання аудиторії спричинені насамперед економічним чинником. Тобто активність інтернет-користувачів залежить від наявності в них фінансових ресурсів. Відтак на початку місяця, коли відбувається видача заробітної плати, кількість користувачів збільшується, а в кінці місяця, коли ресурси вичерпуються, активність знижується.

Тижневі зміни аудиторії інтернету зумовлені такими чинниками:

- календарний чинник (на час відпусток користувацька активність зменшується, а у вихідні дні підвищується);

- зміна режиму праці й відпочинку (у вихідні дні відбувається зменшення кількості користувачів, в будні - збільшення).

Цікавим є й урахування І. Литовченком того, що на людей, які не мають досвіду в мережі, інтернет може все одно впливати через безпосередні зв'язки з регулярними користувачами. Такий вимір називається комунікативним оточенням аудиторії інтернету, яке дослідник розглядає на двох рівнях [4]:

1) ближнє оточення (користувачі без досвіду взаємодіють не менше, ніж з 3 регулярними користувачами);

2) далеке оточення (користувачі без досвіду взаємодіють принаймні з одним регулярним користувачем).

Класифікація аудиторії інтернету залежно від коливань у часі відповідно до різних чинників доцільна під час розробки маркетингової діяльності у віртуальному середовищі.

Інтернет-проникнення $є$ ще однією важливою категорією у веб-аналізі. Інтернет-проникнення (internet-penetration) - статистичний показник аудиторії Інтернету, що визначає, який відсоток населення конкретної місцевості користується мережею.

Цей термін входить в категорійний апарат інтернет-маркетингу, а також застосовується в контексті соціологічного аналізу інтернету. Різниця полягає в особливостях застосування результатів аналізу інтернет-проникнення.

Варто звернути увагу на те, що в науковій літературі під час розгляду якої-небудь проблематики, пов'язаної 3 інтернетом, часто вдаються до здійснення соціально-демо- графічного портрету інтернет-користувача, який зводиться до виявлення статево-вікових характеристик інтернет-аудиторії, освіти, місця проживання та соціального статусу, свого роду кількісних показників. Такі дослідження є корисні і приносять свої результати, проте не розкривають всю глибину присутності людини в інтернеті. Використання термінологічного конструкту «соціальний портрет інтернет-користувача» повинен включати соціально-демографічні характеристики юзерів, тобто той статус, який у них є в реальному житті. Проте портрет користувача має конструюватися також і на аналізі віртуального статусу, на тому, як ідентифікує себе особистість в онлайн-середовищі і особливо - як поводиться в інтернеті (взаємодія, поведінка).

Такого роду підхід прослідковується в праці колективу російських науковців [9] i, що важливо, з використанням концепту «соціальний портрет онлайн-аудиторії». Дослідники інтерпретують це поняття, як сукупність якостей людей у вибірці, їх інтегровані риси, які властиві всій сукупності. Поведінка інтернет-користувачів є вмотивованою, вона часто залежить від навколишньої соціально-економічної та політичної ситуації. Окрім цього, важливим $є$ врахування соціально-демографічних характеристик користувачів. Підхід, реалізований цими науковцями, використовується ними у достатньо вузькій сфері: для регулювання та організації діяльності засобів масової інформації. Зокрема, їх цікавить, як часто слід оновлювати інформацію, яким є характер переданої інформації, сфери інформаційної спрямованості, обсяги та формати матеріалів, а також мова спілкування з аудиторією та умови доступу до її змісту.

Якщо ж розглядати соціологічний дискурс в означеній проблематиці, то у численних дослідженнях і наукових публікаціях популярним $є$ розгляд саме соціально-демографічних характеристиках інтернет-аудиторії на основі проведених опитувань населення. Проте спостерігаються і глибинні дослідження соціального портрету інтернет-користувача. До таких можна віднести праці української соціологині Н. Бойко, яка, використовуючи поняття «соціологічний портрет користувача інтернету», активно досліджує цю проблему. До структури соціологічного портрету інтернет-користувача Н. Бойко відносить показники інтернет-проникнення, соціально-демографічні характеристики та інтернет-поведінку. Відповідно, кожен користувач, здійснюючи певну поведінку, має свій вид діяльності, яку різні науковці по-своєму класифікують. Н. Бойко ж визначає такі сфери активності онлайн: пізнавально-професійна, пізнавально-рекреаційна, соціально-громадська, розважально-ігрова, лінійно-комунікаційна та споживацька актив- 
ність. В рамках досліджень громадянської онлайн-поведінки Н. Бойко виділяє дві групи користувачів: активісти та нонактивісти. Варто зауважити і той факт, що Н. Бойко розглядає і впливи онлайн-активності на реальні соціально-політичні процеси в суспільстві [1, с. 63].

В руслітакогопідходу, колидо уваги береться критерій ступеня активності користувачів, було сформовано і власну типологію, яка здійснена на основі проведеного авторського соціологічного дослідження. Визначено два протилежні типи - активні (активна соціально-політична інтернет-поведінка, яка впливає і на соціально-політичні процеси) та пасивні користувачі (відсутність соціально-політичної інтернет-поведінки). Але окрім цього, було додано ще проміжний між ними вид - слактивізм (поведінка, що зосереджена тільки онлайн і не привносить ніяких результатів) [6, с. 106-107].

Відповідно до певного виду поведінки в інтернеті визначається типаж самого користувача - віртуальний статус, який може зовсім не збігатися з реальним статусом людини. Дослідження типів користувачів $€$ не новим явищем як у соціології, так і в інших науках. Вони розпочалися вже тоді, коли інтернет набув поширення в світі. Як і в разі з інтернет-поведінкою, існує величезна кількість класифікацій користувачів мережі. Але варто, на наш погляд, звернути увагу на працю норвезького дослідника засобів масової комунікації П. Брандцега, в якій науковець провів огляд усіх відповідних досліджень протягом періоду 2001-2010. Перегрупувавши типи користувачів, знайдені в попередніх дослідженнях, П. Брандцег визначив вісім груп користувачів: некористувачі, спорадичні, дебатари, користувачі розваг, соціалізатори, підступники / приховувачі, інструментальні користувачі, досвідчені користувачі. Варто підкреслити, що така типологія здійснювалась на основі активності користувачів та сфери цієї активності [10].

Важливо також зазначити, що формування віртуального статусу відбувається в процесі інтернет-соціалізації, результатом якої $€$ формування віртуальної ідентичності - інтернет-особистості, яка чітко розуміє свої ролі та положення в інтернет-середовищі. В розумінні української дослідниці А. Лучинкіної в процесі інтернет-соціалізації формуються такі типи віртуальної ідентичності: просоціальна (схвалена суспільством), асоціальна (порушує соціальні норми) та антисоціальна (шкодить соціальному устрою). Кожен з цих видів об'єднує в собі ряд віртуальних статусів з певним рівнем включеності онлайн, тобто інтернет-поведінки. Відтак, наприклад, до антисоціальної віртуальної ідентичності з високим мережевим включенням, можна віднести хакерів [5, с. 227]. Розгляд інтернет-залежностей також входить в рамки цього підходу.
Необхідно в контексті соціологічної інтерпретації соціального портрету інтернет-користувача розглянути практику аналізу психологічного профілю користувача мережі. Присутність людини в інтернеті, її діяльність дозволяє здійснювати і психологічну діагностику особистостіта створенняїї психологічного портрету. Різного роду інтернет-технології (блоги, сайти, публікації), особливо соціальні мережі, є невичерпним джерелом інформації про людину, її вподобання, інтереси, симпатії, життєву позицію, характер та активність. Зважаючи на погляди української психологині О. Скуловатової, формування психологічного портрету особистості здійснюється за допомогою цілісного аналізу інформації в інтернеті з таких джерел [7, с. 108-110]:

1. Особиста інформація, яку вказують в спеціальних розділах профілів соціальних мереж. Тут психологи можуть визначити акцентуації характеру, чи бажає людина самоствердження тощо;

2. Адреса електронної пошти, назва якої може містити інформацію про людину. Метафорично - це її офіційне представлення;

3. Нікнейм із психологічного погляду $\epsilon$ специфічним вираженням архетипового змісту свідомості людини. Вибір ніку відбиває несвідомі тенденції та уподобання. Свого роду самоідентифікація.

4. Аватар є візуалізацією образу власного Я, це образ людини, який вона хоче представити оточуючим. Отримати інформацію психологічного характеру можна як із справжнього аватару, так і з несправжнього або символічного;

5. Статус дає інформацію про поточний психологічний стан особистості;

6. Розміщені фото та відео-матеріали на специфічних ресурсах при глибокому контент-аналізі можуть представити велику кількість особистої інформації: звички, цінності, вподобання, інтереси, соціальні зв'язки тощо.

7. Участь в обговореннях та тематичних форумах можливо аналізувати за кількісними та якісними показниками. Кількісно можливо підрахувати ступінь активності людини протягом певного періоду, що може позначати її життєву позицію. Якісний аналіз - аналіз змісту усіх повідомлень.

Доречно також зазначити, що О. Скуловатова піднімає етично-правове питання цієї теми. Проблему неправомірності використання особистої інформації задля створення портрету особистості можна нівелювати такою тезою: людина самостійно розповсюджує інформацію про себе в публічному віртуальному просторі, тому автоматично погодилась на аналіз таких даних. Проте не усю інформацію дозволено аналізувати, оскільки, за словами дослідниці, інформація в інтернеті ділиться на два типи: відкриту та приховану. Відкрита інформація 
вважається публічною, коли до неї має доступ будь-який користувач. Прихована ж інформація характеризується відсутністю до неї доступу або є напівзакритою, тобто доступною певному колу користувачів. На думку О. Скуловатової, для глибинного психологічного аналізу достатньо і відкритих даних [7, с. 107].

Якщо згрупувати названі вченою пункти, то помітно, що деякі характеристики зосереджені на дослідженні соціально-демографічних характеристик, інші на ідентифікації особистості та її поведінкових проявів у віртуальному середовищі.

Зважаючи на характеристики психологічного підходу, з соціологічної точки зору варто зосередити увагу ще на ідентифікації особистості в інтернеті з допомогою візуальних образів, насамперед за допомогою аватару. Звичайно, аватар виконує функцію візуального представлення користувача віртуальній спільноті, відображаючи певним чином його зовнішність та риси і спрощуючи процедуру розпізнання тої чи іншої людини в опосередкованому віртуальному середовищі. Проте часто буває, що аватар продемонстрований нереальним зображенням особистості. Серед таких найпоширенішими формами візуальної ідентифікації у соціальних мережах є: тваринні, мультиплікаційні, зіркові, потойбічні, унікальні, силові, спокусливі. Використання цих візуальних форм користувачами пояснюється рядом причин соціально-психологічного характеру. Часто вони слугують символічним втіленням характеристик користувача (як реальних, так і бажаних), крім цього, допомагають привернути увагу віртуальної спільноти або навпаки, відсіяти тих людей, чиє світосприйняття чи позиція кардинально відрізняється (наприклад, візуальні форми зірок нерідко викликають негативне ставлення інших користувачів через різницю смаків і вподобань). Використання реальних фото користувачами зазвичай спричинено бажанням завоювати довіру або демонстрацією дружнього ставлення до учасників віртуального середовища [8, с. 51]. Надзвичайною популярністю у соціальних мережах зараз користуються так звані «маски» - інструменти для покращення реального фото. Проте цікавими з соціологічної точки зору є маски, які чітко транслюють соціальну позицію людини щодо певних соціальних питань. Наприклад, у соціальній мережі Facebook якийсь час достатньо активно українські користувачі застосовували маску «Один з 25\%», що демонструвала політичну позицію - підтримку на виборах президента кандидата П. Порошенка. Такі маски говорять не лише про наявність певних характеристик особистості, але й про її групову ідентифікацію.

Розглянуті міжгалузеві підходи дозволили реалізувати комплексний підхід до аналізу соціального портрету інтернет-користувача. Першою ланкою для конструювання соціального портрету користувача, очевидно, буде збір наявної інформації. Відповідно, ця процедура може бути здійснена в двох варіантах: по-перше, слідуючи принципам О. Скуловатової, отримання інформації з відкритих джерел, що, з одного боку, дозволяє оминути певні проблеми з етичністю дослідження, але, з іншого боку, існує ризик отримати таким чином поверхневі дані. Інший варіант збору інформації - застосування сучасного програмного забезпечення, що також має свої переваги та виклики. По-перше, одразу виникають проблеми етико-правового характеру, оскільки отримувати непублічні дані без дозволу користувачів заборонено. Розв'язувати таку проблему можна шляхом отримання згоди користувачів, хоча й тут не все буває просто. Не завжди отримати таку згоду можна швидко та легко, а коли йдеться про дослідження з великою вибіркою, тоді цей процес надзвичайно сповільнить хід дослідження. Коли працювати над даними без дозволів респондентів, то результати аналізу викликають одразу шквал обурення з боку суспільства та несуть за собою правові наслідки. Яскраві приклади цьому $\epsilon$ дослідження портретів інтернет-користувача в першій передвиборчій гонці Д. Трампа та в процесі брекзіту у Великій Британії. Попри розголос неправомірності таких досліджень та санкціонування організаторів, вплив їхніх результатів скасувати вже неможливо.

Наступним кроком для з'ясування соціального портрету інтернет-користувача $є$ обробка отриманих даних. Відповідно, така обробка, залежно від методології дослідження, може мати кількісний і/або якісний характер. До кількісних показників можна віднести соціально-демографічні характеристики користувачів (які можна отримати методом опитування чи за допомогою програмного забезпечення), а також такі віртуальні особливості, як інтернет-проникнення, кількість годин перебування в інтернеті, кількість лайків, репостів, переглядів тощо. Якісний аналіз полягає в глибинній обробці інформації: контент-аналіз, дискурс-аналіз, візуальний аналіз, мережевий аналіз сторінки, групи, каналу тощо, а також аналіз інформації, пов'язаної з впливом інтернет-поведінки на реальну діяльність, щодо мотивації для інтернет-присутності (в цьому разі можна використати соціологічний метод глибинного інтерв'ю). Важливо не забувати і про дослідження впливів часових особливостей інтернет-включення аудиторії, соціально-політичної ситуації, які можуть бути причиною тієї чи іншої форми онлайн-поведінки.

Відповідно, отримані висновки повинні описувати важливі компоненти соціального 
портрету інтернет-користувача, тобто з'ясувати соціально-демографічні характеристики користувачів, проаналізувати віртуальну ідентифікацію особистості та виявити особливості її інтернет-поведінки.

Останнім щаблем у дослідженні соціального портрету інтернет-користувача $є$ використання отриманих результатів аналізу. В процесі опрацювання міждисциплінарних підходів виявлялися і специфічні причини проведення таких досліджень, які більшою мірою пов'язані з отриманням економічної вигоди. Якщо розглядати в соціологічному плані, то дослідження соціального портрету інтернет-користувача на макрорівні, коли йдеться про здійснення аналізу якостей вибірки людей, інтегрування рис особистості та екстраполяції на генеральну сукупність, то такі результати можуть знадобитися в процесі регулювання політики держави щодо застосування інформаційно-комунікативних технологій у державотворчих процесах, задля ефективного функціонування інституцій, які впливатимуть і на розвиток громадянського суспільства, розроблення стратегії інформаційної безпеки та й узагалі для підтримання стабільності в суспільстві. Щодо мікрорівня, то знання про компоненти портрету інтернет-користувача, вміння аналізувати відкриту інформацію інших юзерів $є$ необхідною компетентністю окремої людини, оскільки вона стосується безпечної присутності у віртуальному середовищі: як не натрапити на ботів, фейкові акаунти чи шахраїв, як не піддаватися різним маніпулятивним технологіям, що сприятиме підвищенню медіаграмотності, кращого розуміння поширення інформації в інтернеті і взагалі дозволить зрозуміти специфіку віртуального середовища та свого місця у ньому.

Висновки з проведеного дослідження. Зважаючи на зростаючі тенденції використання інтернету в усіх сферах, дослідження соціального портрету інтернет-користувача потребують постійного моніторингу. Крім цього, для більш детального соціологічного розкриття окресленої теми потрібно розглянути ії з погляду емпіричної соціології, що і буде основною метою наших подальших досліджень.

\section{ЛІТЕРАТУРА:}

1. Бойко Н. Громадянська активність онлайн: до соціологічного портрету українського користувача інтернету. Вісник Національного технічного університету України «Київський політехнічний інститут». Політологія. Соціологія. Право: Зб. наук. праць, 2018. № 1 (37). Київ : ІВЦ «Політехніка». C. 61-65.

2. Говорущенко Т.О., Медзатий Д.М., СеменюкВ.С. Метод формування інформаційного портрета користувача в мережі інтернет. Вісник Національного університету «Львівська політехніка». Інформаційні системи та мережі, 2018. № 887. C. 75-80. URL: http:// nbuv.gov.ua/UJRN/VNULPICM_2018_887_12c. (дата звернення: 15.11.2020).

3. Гомзин А.Г., Кузнецов С.Д. Методы построения социо-демографических профилей пользователей сети Интернет. Труды ИСП РАН. том 27. вып. 4, 2015. С. 129-144.

4. Литовченко І.Л. Методологічні аспекти Інтернет-маркетингу : монографрія. Київ : Наукова думка, 2008. 196 c.

5. Лучинкіна А.І. Типологія віртуальних ідентичностей особистості. Вісник післядипломної освіти. 2012. Вип. 8. С. 226-231. URL: http://nbuv. gov.ua/UJRN/Vpo_2012_8_36. (дата звернення: 16.11.2020).

6. Мишок Р.Р. Громадянська інтернет-поведінка львівської студентської молоді: спроба визначення і класифікації. Вісник Національного технічного університету України «Київський політехнічний інститут ім. І. Сікорського». Політологія. Соціологія. Право, 2019. Вип.3 (43). С. 104-110.

7. Скуловатова О.В. Використання даних, отриманих 3 Інтернету, для психологічного аналізу особистості. Науковий вісник Херсонського державного у-ту. Серія «Психологічні науки». 2016. Том 2. Випуск 1. С. 106-111.

8. Соломатова В.В. Специфріка візуальних форм ідентичності в соціальному віртуальному середовищі. Культура України. Серія : Культурологія, 2019. Вип. 64. С. 47-55. URL: http://nbuv.gov.ua/UJRN/ Kukl_2019_64_7 (дата звернення: 17.11.2020).

9. Barb̄akōv O., Vinogradova M., Shatsky A. Social Portrait Of Online Media Audience: Changing Trends and Preferences among Russians. Media Watch. Vol.9, no 3, 2018. P. 383-396.

10. Brandtzæg P., Heim J. Social network sites A typology of users. Journal of Web-Based Communities. vol. 6, no 3, 2010. P. 231-253. 